$$
\text { Pontifícia Universidade C Católica }
$$

Paulo Mendes de Oliveira Junior

\begin{abstract}
A framework for assessing and guiding progress towards a demand driven Supply Chain
\end{abstract}

Tese de Doutorado

Thesis presented to the Postgraduate Program in Production Engineering of the Departamento de Engenharia Industrial, PUC-Rio as partial fulfillment of the requirements for the degree of Doutor em Engenharia de Produção.

Advisor: Prof. José Eugenio Leal

Rio de Janeiro

September 2010 


$$
\text { Pontifícia Universidade } \text { Católica }_{\text {do Rio de Janeiro }}
$$

Paulo Mendes de Oliveira Junior

\section{A framework for assessing and guiding progress towards a demand driven Supply Chain}

Thesis presented to the Postgraduate Program in Engenharia de Produção, of the Departamento de Engenharia Industrial do Centro Técnico Científico da PUC-Rio, as partial fulfillment of the requirements for the degree of Doutor.

Prof. José Eugenio Leal Advisor

Departamento de Engenharia Industrial - PUC-Rio

Prof. Eugenio Kahn Epprecht Departamento de Engenharia Industrial - PUC-Rio

Prof. John H. Vande Vate Georgia Tech. Supply Chain \& Logistics Institute

Prof. Peter Fernandes Wanke COPPEAD/UFRJ

Prof. André Lacombe Penna da Rocha Departamento de Administração - PUC-Rio

Prof. José Eugenio Leal Coordinator of the Centro Técnico Científico - PUC-Rio 
All rights reserved

\section{Paulo Mendes de Oliveira Junior}

Graduated in Nautical Sciences and Machinery from the Merchant Marine School (EFOMM) in 1992. Has a Master of Science degree in International Logistics from the Georgia Institute of Technology, and a Master of Science in Industrial Engineering from Catholic University (PUC). Postgraduate in Marketing and in Management from Instituto de Administração e Gerência (IAG) of Catholic University (PUC), and in Finance from Escola de PósGraduação em Administração Financeira (EPGE) of FGV/RJ. Has global operational experience in the supply chain areas of Planning (Demand, Inventory and Production Planning), Procurement, Logistics and Commercial"

Bibliographic data

Oliveira Junior, Paulo Mendes

A framework for assessing and guiding progress towards a Demand Driven Chain / Paulo Mendes de Oliveira Junior; orientador: José Eugenio Leal - 2010.

$222 \mathrm{f} ; 30 \mathrm{~cm}$

Tese (doutorado) - Pontifícia Universidade Católica do Rio de Janeiro, Departamento de Engenharia Industrial, 2010.

Inclui bibliografia

1. Engenharia industrial - Teses. 2. Logística. 3. Cadeia de suprimentos. 4. Cadeia de suprimento orientada à demanda. I. Leal, José Eugenio. II. Pontifícia Universidade Católica do Rio de Janeiro. Departamento de Engenharia Industrial. III. Título. 
To Betania, Matheus and Valentina, the Center of my Life 


\section{Acknowledgment}

To my Lord, Jesus Christ who gave me the strength to continue in the most difficult periods of this journey and always sustain and guide my life.

To my parents, who strived to provide me the first education and always motivated me to continue my development. I am so thank you for your efforts.

To my advisor, José Eugenio, who gave me the direction and always great motivation to conclude this journey.

To the defense professors, Andre Lacombe, Eugenio Epprecht, John Vande Vate, Kleber Figueiredo, Peter Wanke, who took the time to read this work and participate in the defense session.

To Lou Swanson, who also provided great motivation to finish this work.

To all employees of the industrial engineering department at PUC/RJ for their support and always good will in all situations. 


\section{Abstract}

Oliveira Junior, Paulo Mendes; Leal, José Eugenio (Advisor). A framework for assessing and guiding progress towards a demand driven Supply Chain. Rio de Janeiro, 2010. 222p. Tese de Doutorado. Departamento de Engenharia Industrial, Pontifícia Universidade Católica do Rio de Janeiro.

Several companies have been implementing forecasting tools and processes to improve demand planning performance, but these initiatives were not enough to eliminate oOS problems, and improve supply chain efficiency, due to a mismatch between supply and demand, low forecast accuracy for medium and low volume products, high demand variability and/or high number of new product introductions. To cope with this scenario, most companies are trying to move from a pure Push strategy, which is to produce and distribute based only on forecast, to a Pull system, which is to operate based on actual customer demand, in order to balance supply availability with customer demand. This thesis aims to identify and describe the key components of demand driven supply chains and based on these components, develop a structured and integrated assessment framework that companies can use to assess their current and desired future supply chain states in light of the Demand Driven Supply Chain (DDSC) concepts, and to define a supply chain strategy to move towards a customer centric operation, cost effectively. The framework was applied in three supply chain operations of a global beverage company in USA, Brazil and Uruguay to validate the methodology and formalize an action plan for these operations to be able to move towards a DDSC. The results of the assessment showed that two operations are currently close to a basic push level, and one is closed to an optimized push level, confirming that there are clear opportunities for those companies to improve their performance based on demand driven concepts. Finally, another contribution of this thesis is the structured framework developed to design a three year supply chain strategy, which will consider the DDSC assessment results as one of the key inputs, and will support the implementation of the opportunities identified during the assessment.

\section{Keywords}

Logistics, Demand Driven Supply Chain. 


\section{Resumo}

Oliveira Junior, Paulo Mendes; Leal, José Eugenio (Orientador). Um arcabouço para avaliar e guiar a evolução em direção a uma cadeia de suprimentos orientada à demanda. Rio de Janeiro, 2010. 222p. Tese de Doutorado. Departamento de Engenharia Industrial, Pontifícia Universidade Católica do Rio de Janeiro.

Diversas empresas implementaram processos e ferramentas de previsão de demanda para melhorar a performance do planejamento de demanda, porém estas iniciativas não foram suficientes para eliminar problemas de ruptura de produtos, melhorar a eficiência da cadeia de suprimento, devido ao desbalanceamento entre oferta e demanda, baixa precisão da previsão de demanda para produtos de médio e baixo volume, alta variabilidade de demanda e / ou grande número de novos produtos lançados no mercado. Para operar neste cenário, muitas empresas estão fazendo a transição de uma estratégia pura de "push", no qual os produtos são manufaturados e distribuidos baseado somente em previsão de demanda, para uma estratégia de "pull" baseada na demanda real dos clientes, de forma a balancear a disponibilidade de produto com a demanda dos clientes. sta tese busca identificar e descrever os componentes de uma cadeia de suprimento orientada à demanda e, baseado nestes componentes, desenvolver uma metodologia estruturada e integrada para avaliar o estado atual das empresas à luz destes conceitos, assim como definir uma estratégia para auxiliar as organizações se tornarem orientadas à demanda com um custo eficiente. A metodologia foi aplicada em três regiões de uma empresa global de bebidas nos Estados Unidos, Brasil e Uruguai para validar a metodologia proposta e formalizar um plano de ação para estas operações se moverem na direção de "orientadas à demanda". Os resultados da avaliação demonstraram que duas operações estão próximas ao nível básico de "push" e uma está próxima ao nível otimizado "push", confirmando que existem claras oportunidades para estas empresas melhorarem sua performance com base nos conceitos propostos. Finalmente, outra contribuição desta tese é o arcabouço proposto para desenho de uma estratégia de três anos para a cadeia de suprimento, o qual irá considerar os resultados da avaliação como uma das principais entradas, e irá gerar um plano de ação para suportar a implementação efetiva das oportunidades identificadas durante a avaliação, permitindo que as organizações se tornem orientadas à demanda.

\section{Palavras-chave} Demanda.

Logística, Cadeia de Suprimentos, Cadeia de Suprimento Orientada à 


\section{Thesis Summary}

$\begin{array}{ll}1 . & 10\end{array}$

1.1. Initial Thesis Overview 10

1.2. Current Market and Business Environment 12

2. Literature Review on Demand Driven Supply Chain 14

2.1. $\quad$ Demand Driven Supply Chain Concepts 14

2.2. Methodologies for Assessing Demand Driven Supply Chain 29

2.3. Benefits of Demand Driven Supply Chain 37

3. Proposed Framework 38

3.1. Briefly Review of Research Design 38

3.2. $\quad$ Building Theory from Case Study Research 44

3.3. Research Method for Developing DDSC Assessment
Framework

3.4. Proposed DDSC Framework 51

4. $\quad$ Key Components of Demand Driven Supply Chain (DDSC): 57

4.1. Supply Chain Processes $\quad 57$

4.2. Components of Demand Driven Supply Chain 60

4.3. Demand Management (DM) 61

4.4. $\quad$ Supply \& Operations Management (S\&OM) 92

4.5. Product Lifecycle Management (PLM) 131

5. Proposed Demand Driven Supply Chain Model 152

5.1. Introduction 152

5.2. Demand Driven Supply Chain Maturity Model 153

6. Analytic Hierarchy Process (AHP) 181

6.1. Introduction to Analytic Hierarchy Process 181

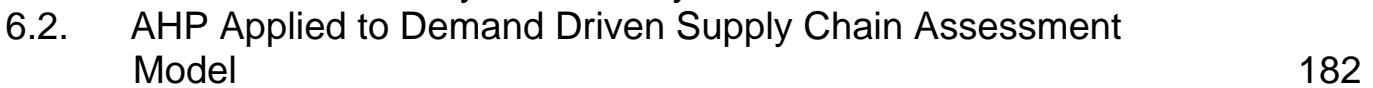

7. Validation Implementation in the Beverage Segment 187

7.1. Data Collection 187

7.2. Results of Application in 3 operations - Uruguay, Brazil, United
States

7.3. Develop Supply Chain Strategy to Become Demand Driven 200

8. Summary and Future Developments 212

9. References 214 